\title{
MODERNIDADE E PÓS-MODERNIDADE
}

Há um debate importante entre os defensores da existência de uma condição pós-moderna e os que acreditam que a modernidade ainda não se esgotou. Entende-se por modernidade a era em que o desenvolvimento do conhecimento humano passou a ter por base a razão, especialmente na sua dimensão instrumental, e a ciência moderna, que surge a partir dos séculos XVI e XVII, se integrando às esferas econômica, política, cultural e social.
Nas décadas de 1970 e 1980, vários autores afirmaram que a modernidade estaria dando lugar à pós-modernidade, quando as grandes narrativas seriam rejeitadas e substituídas por teorias contingentes e localizadas. Esse debate traz implicações de caráter ontológico que refletem diretamente na construção do conhecimento na Administração. Mario Aquino Alves, professor da FVG-EAESP, recomenda as seguintes obras:

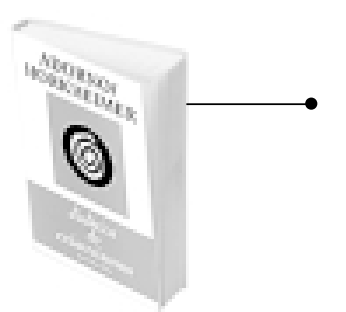

DIALÉTICA DO ESCLARECIMENTO: fragmentos filosóficos. Theodor W. Adorno e Max Horkheimer. Rio de Janeiro: Jorge Zahar Editor, 1985. 256 p.

Este trabalho procura explicar como o Iluminismo e a modernidade criaram uma promessa de libertação do ser humano das restrições da natureza e do mito, tornando possível o controle sobre a natureza por meio da ciência, a abundância material por meio de alta tecnologia e a eficiência de governo por meio da organização racional da sociedade. Os autores mostram a contradição do Iluminismo, que traz em seu bojo a própria regressão, o retorno às formas primitivas que levam à destruição e ao próprio aprisionamento do indivíduo.

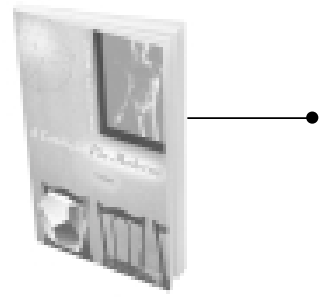

A CONDIÇÃo PÓS-MODERNA. Jean-François Lyotard. Rio de Janeiro: Ed. José Olympio, 2002. 132 p.

Escrito em 1979, este livro é uma das primeiras obras a difundir o uso do termo "pós-moderno". Para o autor francês, "pós-moderna" é a condição histórica e cultural da sociedade capitalista contemporânea, que sofreu fortes transformações, especial mente calcadas na dissolução das grandes narrativas do Iluminismo - as metanarrativas - e das ideologias revolucionárias do século XIX, que legitimavam tanto as regras do conhecimento das ciências quanto as instituições modernas.

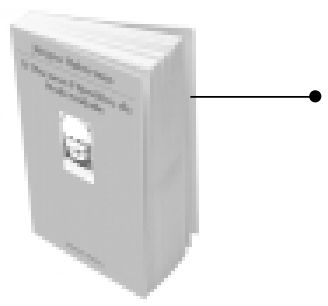

O DISCURSO FILOSÓFICO DA MODERNIDADE. Jürgen Habermas. São Paulo: Editora Martins Fontes, 2000.540 p. Nesta obra, escrita em 1985, o filósofo alemão faz uma tentativa de resgate do projeto da modernidade, que para el e se configura como incompleto. Em uma crítica à filosofia pós-moderna - ou pós-estruturalista francesa - Habermas defende a idéia de que o projeto da modernidade deveria ser reconstruído (não desconstruído) com bases no resgate da razão comunicativa como força emancipatória.

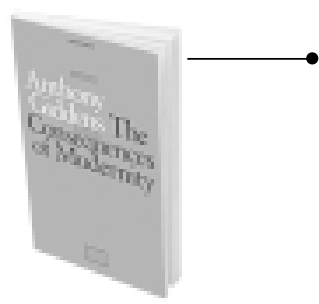

THE CONSEQUENCES OF MODERNITY. Anthony Giddens. Cambridge: Polity Press, 1990. 186 p.

0 autor situa a modernidade nas formas de vida social ou de organização que surgiram na Europa a partir do século XVII e que se espalharam pelo mundo. Afirma que não vivemos em um mundo pós-moderno, mas que estamos experimentando um período de "alta modernidade", no qual a des-tradicionalização do mundo e o desencaixe (disembedding) das relações sociais de contextos locais de interação para novos ajustes de tempo e espaço se tornam cada vez mais radicais e universais.

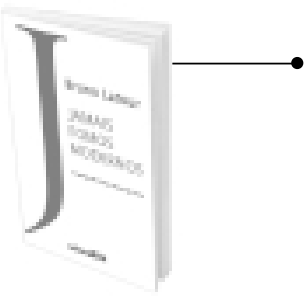

JAMAIS FOMOS MODERNOS: ensaio de antropologia simétrica. Bruno Latour. São Paulo: Editora 34, 1994. 152 p. 0 autor retoma a questão do domínio da natureza pela cultura como um traço característico da modernidade. Afirma que nos últimos anos houve uma combinação do natural e do cultural, que se mostra por meio da mídia, e que faz convergir a política, a ciếncia e a natureza em discursos. M ostra que as sociedades pré-modernas são o resultado híbrido desta combinação e que a sociedade "moderna" nunca teria funcionado baseada nos princípios da separação entre ciência e cultura, decorrendo disso a sua tese de que jamais tenhamos sido modernos. 